Portland State University

PDXScholar

1972

\title{
A Scale of Verbal Accessibility in Mild and Borderline Retarded Adults
}

Keith Baker

Portland State University

Follow this and additional works at: https://pdxscholar.library.pdx.edu/open_access_etds

Part of the Social Work Commons

Let us know how access to this document benefits you.

\section{Recommended Citation}

Baker, Keith, "A Scale of Verbal Accessibility in Mild and Borderline Retarded Adults" (1972). Dissertations and Theses. Paper 2543.

https://doi.org/10.15760/etd. 2540

This Thesis is brought to you for free and open access. It has been accepted for inclusion in Dissertations and Theses by an authorized administrator of PDXScholar. Please contact us if we can make this document more accessible: pdxscholar@pdx.edu. 


\section{A SCALE OF VERBAL ACCESSIBILITY}

IN MILD AND BORDERLINE

\section{RETARDED ADULTS}

by

KEITH BAKER

A report submitted in partial fulfillment of the requirements for the degree of

MASTER OF SOCIAL WORK

Portland State Unfversity

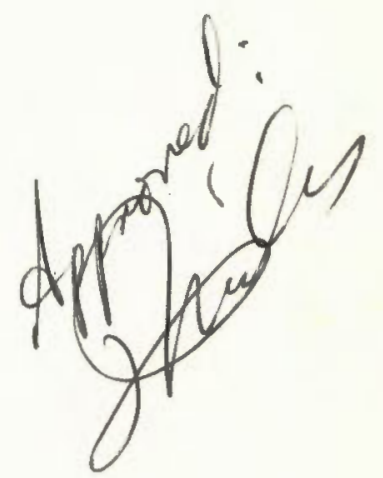
1972 
TABLE OF CONTENTS

Chapter

Page

I. INTRODUCTION 1

$\begin{array}{ll}\text { Purpose } & 1 \\ \text { Rationale } & 2 \\ \text { Concept of Verbal Accessibility } & 5 \\ \text { Summary } & 7\end{array}$

II. METHOD 8

Construction of the Scale 9

Scoring 11

Administration of the Scale 13

The Sample 15

Analysis of the Sample 17

$\begin{array}{ll}\text { III. RESULTS } & 19\end{array}$

Data Compilation $\quad 20$

Data Analysis $\quad 22$

$\begin{array}{ll}\text { Validity } & 27\end{array}$

IV. EVALUATION AND IMPLIGATIONS 20

Theoretical Implications 28

Clinical Implications 29

Implications for Further Research 30

BIBLIOGRAPHY 32

$\begin{array}{ll}\text { APPENDIX } & 34\end{array}$ 


\section{A SCALE OF VERBAL ACCESSIBILITY \\ IN MILD AND BORDERLINE \\ RETARDED ADULTS}

CHAPTER I

INTRODUCTION

This is the forth study of verbal accessibility undertaken at the Portland State UnIversity School of Social Work. The first two completed in the years 1967 (Kriesse, et al., 1967) and 1968 (Walker, et al., 1968) dealt with the area of marriage. The third completed in 1969 (Metz, et al., 1969)dealt with the authoritarian family ideology. The intent of this study is to determine if that material can be applied to use with the retarded adults being placed from Falrview Hospital and Training Center. This is the mafor State Institution for care and treatment of the mentally retarded in the State of Oregon.

\section{Purpose}

The major purpose of the present research profect was an exploratory study of the development of a scale to measure one aspect of what is involved in the success or fallure in the. placement of the adult $\mathrm{mlld}$ and borderline retarded individuals from Institutional life into that of general community living. Polansky (1965) defines verbal accessibility as readiness to 
communicate verbally, and to participate in communication about determinant attitudes. As reported by Kresse, et al. (1967), Polansky states that determinant attitudes are "those attitudes (tendencles to act) whose change seems most likely to bring about strong changes in other related attitudes." They also cite Appelberg (1961) as clarifying this concept by stating that determinant attitudes influence the way an individual functions; they are basic, formed early in life, and are typically unconscious.

This present scale was intended to measure the verbal accessibility of consclous derivatives of these key attitudes in and around the life needs of the retarded adult.

\section{$\underline{\text { Rationale }}$}

The rationale for utilizing verbal accessibility in the study of placement of $\mathrm{mlld}$ and borderline retarded adults is as follows:

1. Investigation of verbal communication should yleld significant data for the understanding of process of interaction of the retarded adult with those other people in his/her Iffe who affect their patterns of behavior.

2. Verbal accessibility is an important aspect of verbal communication. If a person is able to get close to another individual through forming a relationship and the communication that follows, there will be more favorable prospect 
for success especially in moving from institutional living to community living.

3. Verbal accessibility is related to the individual's capacity for self-observation. Interaction between two verbally accessible people reduces anxiety and enhances the expression and development of each person's self. The retarded adult who has spent a considerable part of his life in institutional living definitely needs to be able to observe and discuss things as he faces new experiences in the community. He may fear verbalizing attitudes to people of importance to him such as relatives, friends, home providers, or counselors.

4. Differences between the level of verbal accessibility of the retarded adult and his own concept of his verbal accessibility may indicate discrepancies of thought. If the retarded adult feels that he is verbally accessible to his home provider, for instance, but in actuality the home provider does not feel that the individual is willing to communicate, this will have a significant impact on the success of their problemsolving efforts together.

5. Verbal accessibility skills are thought to be of greater importance for placement success of the individual leaving the institution than are fob skills. This is based on the experience of placement and follow-up social workers who have found that even the best trained and the more intelligent retarded adult being placed outside the institution will not necessarily be successful while a less capable and less well 
trained retarded adult may be successful in spite of the greater handicap.

6. It is felt that each person who is placed from the institution needs to have at least one person that he is highly verbally accessible to in order that he might succeed. If a person has never been able to come to another person and talk about areas that are bothering him, it would be expecting too much for that person to come for help to someone in the time of crisis. If the individual does finally come for help, it may be too late to make any practical let alone Ideal changes to prevent damaging problems.

7. Various people are more important than others for one person or another. The retarded person may or may not be verbally accessible to the person who is important to him or her. Sometimes relatives or friends are important but are not the people whon the client will talk with about important issues of concern.

8. Some people who are in the role of either home provider or counselor to the retarded adult are able to inspire more willingness to communicate in the retarded adult. Some clients are more verbally accessible to one worker than they are or would be to another. If this were known and predictable, It would be of assistance in the placement program.

9. If one could measure accurately the degree of verbal accessibility of a specific individual and could know how willing other clients have been to talk with a certain 
home provider and also with a certain counselor, one could, at least theoretically, predict success or fallure. One could also be aware of certain potential problems and work toward solving them before they became insurmountable.

The Concept of Verbal Accessibility

Communication is central in the studies and work with placement of the retarded adult into community settings from institutional living. In this study communication is defined according to Ruesch and Bateson (1951) as "all those processes by which people influence one another." They describe four levels of communication as Intrapersonal, Interpersonal, Group, and Cultural. Each of these levels of communication is Important but only the Interpersonal or the one to one level is measured In this study. The interpersonal level can be sald to be that of an exchange of recelving, transmitting and evaluating messages. Thus, communication is an active process requiring participation from each person involved.

Although the Importance of non-verbal communication cannot be disputed, verbal communication has the distinct advantage of belng easily avallable for research. Also the method of changing attitudes and behavior is through the verbal means. Casework relies heavily on verbal communication to accomplish tts goals as do many other modes of changing human behavior. 
Polansky (1965) defines verbal accessibility as the "degree of readiness of the client (or patient) to communicate verbally, and to participate in communication about, his determinant attitudes." The meaningful unit of communication Is not just the "facts" given by the client nor just the "feelings" but the set of attitudes which characterize him. Polansky has expressed that the more a subject 1s willing to discuss, the more 1ikely he is to expose determinant attitudes.

A part of the verbal accessibility of a person is his verbal accessibility of an attitude. Th1s can be considered In two senses: (1) an Individual may be more willing to discuss certaln of his attitudes than he will others; and (2) examination of a number of Individuals may reveal uniformitles in regard to expressing or not expressing certain attitudes.

My concern In this study is with the aspect of verbal communication that has thus been conceptualized as verbal access1b111ty. In their Master's Thesis (Kresse, et al., 1967) they made a comprehensive analysis of the concepts and background of the term verbal accessibility. S1nce their study there has been essentially no change in the use of these concepts in the soclal work 11terature. Therefore, I am not making any attempt to include such a review of the 11terature.

In attempting to study verbal accessibility as $1 t$ relates to the speciffc area of mental retardation, I have made a comprehensive study of the literature dealing with mental retardation and can find absolutely no reference or study which 
has previously been made of the relationships between verbal accessibility and the placement and success of the retarded adult individual. In fact there is no mention of this concept In the literature relating to mental retardation.

\section{Summary}

In this chapter I have considered why there is a concern to study this aspect of placement and adjustment of the mild and borderline retarded adults placed from the State Institution. In order to be able to study this aspect, this profect was designed to develop a scale of verbal accessibility for this intellectual level and afmed toward the concerns and attitude problem areas of those being placed Into community facllitles. I have also stated my rationale for belfeving that a scale of verbal accessibility is potentially a significant tool for the clarification of concerns and confusion about the appropriate timing for placement.

Although a measurement of verbal accessiblitty is not necessar1ly an only measurement of success prediction, it does attempt to cover a large gap in the field.

This chapter has also briefly summarlzed the concept of verbal accessibility and Indicated that there have been no previous studies of verbal accessibllity with the retarded adult especlally as it relates to a placement setting. There have been previous studies and summaries of the literature of verbal accessibility relative to other sample populations. 
CHAPTER II

METHOD

In this study, my major focus has been on developing an instrument for measuring verbal accessibility of the mild and borderline retarded adult being placed into community situations from institutional 11ving. As stated earlier, there are no studies directly concerned with mental retardation, but there are those scales which did offer a considerable body of theory, method and techniques for measuring verbal accessibility. I felt that these techniques could be adapted to the specific alms of this project.

The research approached developed by Norman Polansky and Sidney Jourard and their associates served as a background for the development of my scale. Jourard and Lasekow (1958) described a questionnaire method for measuring the amount and content of self-disclosure to selected "target persons." Jourard and Richman (1963) developed a questionnaire which was designed to assess the amount of self-disclosure as a variable in its own right. Polansky, Welss and Blum (1961) used a scale analysis technique to study verbal accessibility as a function of content and personality with children treatment. Appelberg (1961) developed a series of scales to measure verbal accessibility of adolescents. The Appelberg scales were designed to measure both verbal accessibility of an individual and of a particular 
attitude. Verbal accessibility of the individual was determined by how much that individual was willing to discuss, and let others discuss with him, important feelings. Appelberg measured the verbal accessibility of the individual by counting how many items on the scale the individual was willing to discuss with a specifled target person. The verbal accessibllity of an attitude was measured by counting the number of individuals who were willing to discuss the attitude with a specified target person. I have attempted to use this final type of approach, with the necessary adjustments in content areas, target persons, and wording of the items to sult the retarded adult population being studied.

\section{Construction of the Scale}

To facilitate and organize the selection of items for the scale, it was decided to use content areas suggested by social roles. There was no attempt to study roles as such, but to use them as a frame of reference for selecting question items. Five areas of important feelings and concerns for the young retarded adults are: peer status; parental type roles, as usually seen in a non-relative Home Provider; attitudes toward self, as affecting independence-dependence; work roles or job adequacy; and sexual ident1ty.

The most important criterion for the selection of items was the "determinancy" of the attitude represented by the 1 tem. 
I was attempting to study the degree to which individuals are ready and willing to communicate important feelings. By determinant attitudes 18 meant those attitudes which are most "basic" to the personality functioning of the Individual, and which have the most weight in influencing behavior.

The language had to be kept simple and informal for the Intellectual and comprehensive level of the clients. Before any actual interviewing use was made of the questions, they were given to professional soclal workers, educators, and a psychologist for review as to their understandability. Each of these professionals was famillar with the ability levels as well as the spoken language and understanding ability of the target population. It was my attempt to develop statements which would be understood in the same way by each client.

To avold statements that might be understood to refer to actual happenings in the client's life, each question was structured to read in the same way: "Suppose that you (had a certain feeling or concern), would you talk with (a specifled target person) about 1t?"

Four target persons were used in this research. The target persons selected were Home Provider, Relative, Friend, and Counselor. Clients were asked to name each of the target persons with whom they would most 1ikely discuss important feelings and concerns. The majorlty of the clients were living in group living facilities and they frequently had a choice of more than one person who was operating in the role of Home Provider. The 
Relative target was not limited to parental figures to eliminate the possibility that parents were dead or no longer Involved in the client's life. The Friend target person could be of the same or opposite sex but it was suggested that the Individual be of similar age so that the relationship would be of a peer type. Each of the clients was assoclated with one or more counselors and thus the client sometimes was faced with a cholce as to which he felt most willing to discuss important feelings and concerns. One reason for using the counselor as a target person was that this person could be utilized as a possible cross check by asking the counselor to rate the clients also. Four response categories were selected to indicate the degree of accessibility. The client could choose the category which best represented the extent of his willingness to communicate with a target person about each item. The categories were: "Definitely Yes;" "Probably Yes;" "Probably No;" and "Definitely No." Consideration was given to just offering the choice between "yes" and "No" but it was decided that even though some would not be able to completely descriminate on the four levels, it was important to give each the opportunity to have as much freedom of choice as possible. The responses could be consolidated later if desirable for data analysis.

\section{Scoring}

Welghts of $4,3,2$, and 1 were assigned the categories on the assumption that they represented equal intervals. The highest 
weight was assigned to the most positive category and the lowest to the most negative. In this way a score could be obtained for ranking between high and low accessibility. A score sheet, a copy of which is included in the Appendix, was constructed to show a total score for the individual, for the target persons and for each item.

In addition to the ratings of the clients for each of the four target persons, the Home Provider and the Counselor were asked to rate how much verbal accessibility they felt the individual had to them. This would function as a cross check of reality.

The number of items used in this scale was partially determined by a time factor. The attention span of the sample population was expected to not exceed one-half hour. From pretesting it was determined that even if each question had to be stated for each target person, that up to twenty-five items could be handled within this time $11 \mathrm{mit}$. Item selection was made and the scale finally had a total of twenty-four 1tems. Since each Item required a response for four target persons, the client was asked to make a total of ninety-six decisions during the interview. Most clients moved through the 1tems in less than the one-half hour without fatigue. There were no refusals to cooperate and they considered the testing as a valid part of follow-up of their training program. Clients were told that their responses and scores would be kept confidential unless they requested specific counseling relative to their responses. Data collection 
extended over a perfod of three months. Descriptive data about the sample population was collected effective December 31, 1971. This Includes their age, number years in Falrview prior to their placement, duration of employment, and time between placement and December 31, 1971. This data can be found on Table I later in this chapter.

\section{Administration of the Scale}

The scale was administered to clients in an one-to-one setting. Introduction and instructions were glven verbally. Uniformity of presentation was a goal. All interviews were done by one individual. A copy of the instructions is included in the Appendix.

Each 1tem was typed on $3 \times 5$ cards with large primary type for easy reading. There were four different cards. They were placed in stacks side by side in front of the clients. Each color represented a different target person and was so labeled. Each stack of cards contained twenty-four cards with the questions. Behind the card stacks were individual blank cards of corresponding color. As the session began these cards were blank but when the client identified each of the target persons I wrote the name on the appropriate card. This helped me as well as the client maintain consistency when seeking to personalize the question items. Behind the cards was a box with four compartments which was marked with the response categories. The 
client "voted" each card by inserting it into the response box opening which best represented how much he would talk with a target person about that particular item. Judgments were made in regard to all four target persons before moving on to the next item. A sample question was used in the instructions and was on the top of the card stacks to introduce the clients to the mechanical procedures. The interviewer read aloud each 1 tem as It came up so that the cllent had the advantage of both a visual and an oral presentation. This is important as many have some difficulty in reading.

For ease in scoring, each card was numbered and the same sequence of 1tems was used with each client. Definite effort was made to start and finish the sequence with "easy" or nonthreatening 1 tems, but otherwise no ordering of 1 tems except by general subject groupings was attempted. It was assumed that the degree of responses to the items would reflect an underlying order. Scoring was quite simple as the response box in which a card was found after the interview indicated the weight of the answer. The color of the card Indicated the target person and the item Identification number was typed on the card.

Additional data were collected from each client and from institutional files regarding age, number of years client had spent in the institution prior to placement, the number of weeks the client was in a training program, the number of weeks the client worked under an 0 . J. T. (On Job Training) contract, the reason this $0 . \mathrm{J} . \mathrm{T}$. ended, the total number of weeks the 
client was employed after the end of the 0 . J. T. contract, the number of weeks between the placement and December 31, 1971, and intelligence quotient These data factors provided for analysis which might influence verbal accessibility as well as success in the community. Each Counselor and each Home Provider rated the client as to how much the client would talk to him about the 1tems. These scores could then be compared to the client's self-avowed accessibility to both the Counselor and the Home Provider. The form for the Counselor and Home Provider ratings is located in the Appendix.

\section{The Sample}

The sample population used in this study was limited to individual clients who had been trained in the 1969-70 MDTA (Manpower Development Training Act:) program operated through the Vocational Training Department of Fairview Hospital and Training Center in Salem, Oregon. The Individual clients, all over age 18 are prepared for work placement in the community in this program. The training is divided into two parts. Initially the Individual recelves basic education and fob training as kitchen helpers, maids, nursing home orderlies and janitorial helpers. This training and education part of the program is done on the grounds of Fairview. The second part of the program involves their being placed on a job in the community (if they are suited) under a contract with an employer whereby he must pay the worker 
the standard minimum wage for approximately 15 weeks. He is reimbursed for his training expenses after the 0 . J. T. contract period is completed. Following the 0. J. T. contract the client may be hired at regular minimum wage if the employer is satisfied with the individual's performance. However, if he is not satisfled, he can fire the client and is not in any way obligated to continue to employ the client if his production is not adequate. Everyone who could be contacted and who was living within the Willamette Valley was included in the sample. The total sample that responded to the scale numbered forty of which twenty were male and twenty were female. They were interviewed in a varfety of settings. These included in their living quarters, at work, and in an office at Fairview. Although the personal interview method limited the number of clients which could be included in the sample within a reasonable time allotted for data collection and a reasonable travel expense, it was felt to be superior to a questionnaire method. The majority of the sample do not have the capabilities to make responses of this nature and send them back. By direct, individual contact, I could explain the instructions in greater detall to the clients. I also wanted to directly observe the client's responses to both the procedures and the 1tems.

Within the sample population there were definite groups who had been successful in community placement and other groups who had been unsuccessful and many of this last group had been returned to the institution. This would provide contrast. 
The cllents within the sample had counselors avallable to them as needed. MDTA provided some follow-up counseling. Some clients were no longer having any contact with the MDTA counselor and may have considered a Field Representative from Fairview, a Vocational Rehabilitation Counselor, or a Welfare Caseworker as the1r "Counselor."

I made individual appointments for each of the clients to participate in the scale. There were no refusals to participate in the scale, but it is quite possible that the authority of the institution influenced the client's willingness to cooperate. I personally knew many of the client's as I had worked for the institution prior to Graduate School.

Analysis of the Sample

The age at placement for the males and females in the sample showed considerable difference. The mean age of the males was 22.25 in contrast w1th 27.05 years for the females. The males spent slightly more years in the institution prior to placement than did the females. The mean for the total sample was 9.8 years. While the sample population was involved in the training program it appears that either the males were nearer being ready for placement at the time the program began or developed faster. The males only spent a mean time in the trainIng program (before they were placed) of 23.60 weeks wh1le the mean for the females was 32.25. This is interesting in that the intelligence was very close between males and females with the 
females having a slight edge over the males of 68 for females and 65 for males.

When the sample was placed on an 0 . J. T. contract to work in the community they were able to stay a mean of 10.08 weeks with a range from zero to 29 weeks. The most significance between the males and females was in the number of weeks that they were able to keep the first fob after the government subsidy of the 0.J. T. contract expired. The males were able to keep that first job a mean of 31.15 weeks while the females were only able to keep it a mean of 15.60 or approximately $50 \%$ as long.

\section{TABLE I}

ANALYSIS OF THE SAMPLE POPULATION (MEANS)

\begin{tabular}{lccc}
\hline \multicolumn{1}{c}{ Varlable } & Females & Males & Total Mean \\
& & & \\
\hline Age at Placement & 27.05 & 22.25 & 24.60 \\
Years in Fairview & 9.20 & 10.40 & 9.80 \\
Weeks in Training Program & 32.25 & 23.60 & 27.93 \\
Weeks on 0. J. T. & 10.15 & 10.00 & 10.08 \\
Weeks kept first fob & 15.60 & 31.15 & 23.38 \\
Weeks employed from end of & 28.05 & 44.55 & 36.30 \\
0.J.T. to 12-31-71 & & & 88.55 \\
Time period involved in weeks & 81.45 & 65.00 \\
Intelligence Quotient & 68.15 & 65.30 & 67.73
\end{tabular}


It was planned that the scale developed would measure the variable "verbal accessibility" In such a way that the persons as well as 1 tems could be ranked along a continuium from least accessible to most accessible. The scale was constructed to contain twenty-four Items and tapped an unknown number of attitudes. Rather than undertake an extensive analysis of the responses to each of the questions, for the basis of this exploratory study, It was assumed that, if the questions were closely matched as to question style and subject matter, one could rely on past research of Kresse, et al., (1967) and Appelberg (1961). Th1s past research had determined that an instrument measuring attitudes as done in this present study did measure verbal accessibility.

Freed from this lengthy analysis I was able to give more consideration to looking at the interrelationships between a person's self-avowed verbal accessibility to various target people and the roles that they represented with several other factors. With the exception of a few correlations and some chi squares the results of this research are belng analyzed through looking at general trends instead of relylng on data analysis completely. 
Data Compilation

The data from the self-avowed verbal accessibility Interview as well as from the Counselor and Home Provider Ratings was compiled and placed on IBM computer punch cards in the hope that computer data analysis could greatly simplify analysis. However, the time to prepare the data for computer analysis was too lengthy and the only use of this process was to utilize a card sorter to complle the number of "Definitely Yes," "Probably Yes," "Probably No," and "Definttely No" responses for the twenty-four items in each of the six ratings (four by client and two by other people about the client). By assigning values of $4,3,2,1$ respectively to the above responses I was able to arrive at a number value which I could identify as representing the verbal accessibility for elther an individual client or a mean score for a specific question of the scale. Table II shows the verbal accessibllity scores for the twenty-four questions as to how the forty cllents felt they were wllling to be accessible to the four target people. It also shows the verbal accessibility scores for the Counselor and Home Provider's ratings along with the mean scores for the combined self-avowed verbal accessibility and the mean scores for the ratings done by the other people.

It is interesting to note that the self-avowed verbal accessibility score to the Home Provider is much higher than any of the other scores. This could mean several things. First, 
TABLE II

TOTAL SCORES FOR ENTIRE SAMPLE

\begin{tabular}{|c|c|c|c|c|c|c|c|c|c|c|}
\hline \multicolumn{7}{|c|}{ Self-Evaluations of: } & \multicolumn{4}{|c|}{ Evaluations by: } \\
\hline Item & $\begin{array}{l}\text { Home } \\
\text { Pro- } \\
\text { vider }\end{array}$ & $\begin{array}{r}\text { Rela- } \\
\text { tive }\end{array}$ & $\begin{array}{l}\text { Fri- } \\
\text { end }\end{array}$ & $\begin{array}{l}\text { Coun- } \\
\text { selor }\end{array}$ & Mean & Rank & $\begin{array}{l}\text { Coun- } \\
\text { selor }\end{array}$ & $\begin{array}{l}\text { Home } \\
\text { Pro- } \\
\text { vider }\end{array}$ & Mean & Rank \\
\hline 1 & 137 & 105 & 98 & 121 & 115.25 & 4 & 108 & 132 & 120.00 & 20 \\
\hline 2 & 137 & 126 & 101 & $124]$ & 122.00 & 15 & 92 & 114 & 103.00 & 4 \\
\hline 3 & 136 & 123 & 106 & 127 & 123.00 & 17 & 96 & 125 & 110.50 & 10 \\
\hline 4 & 138 & 121 & 111 & 127 & 124.25 & 20 & 98 & 129 & 113.50 & 12 \\
\hline 5 & 149 & 131 & 118 & 140 & 134.50 & 24 & 107 & 126 & 116.50 & 19 \\
\hline 6 & 125 & 104 & 97 & 103 & 107.25 & 1 & 101 & 115 & 108.00 & 9 \\
\hline 7 & 126 & 115 & 104 & 118 & 115.75 & 6 & 107 & 120 & 113.50 & 13 \\
\hline 8 & 144 & 133 & 104 & 122 & 125.75 & 23 & 107 & 125 & 116.00 & 18 \\
\hline 9 & 133 & 117 & 89 & 123 & 115.50 & 5 & 107 & 121 & 114.00 & 15 \\
\hline 10 & 144 & 109 & 102 & 125 & 120.00 & 10 & 116 & 126 & 121.00 & 21 \\
\hline 11 & 144 & 114 & 103 & 121 & 120.50 & 14 & 95 & 106 & 100.50 & 3 \\
\hline 12 & 122 & 108 & 99 & 118 & 111.75 & 3 & 101 & 109 & 105.00 & 6 \\
\hline 13 & 142 & 121 & 96 & 122 & 120.25 & 11 & 107 & 118 & 112.50 & 11 \\
\hline 14 & 132 & 121 & 101 & 141 & 124.50 & 21 & 120 & 124 & 122.00 & 22 \\
\hline 15 & 139 & 126 & 99 & 125 & 122.25 & 16 & 92 & 118 & 105.00 & 5 \\
\hline 16 & 144 & 130 & 96 & 130 & 125.00 & 22 & 102 & 126 & 114.00 & 14 \\
\hline 17 & 125 & 106 & 102 & 134 & 116.75 & 7. & 115 & 113 & 114.00 & 16 \\
\hline 18 & 130 & 106 & 102 & 136 & 118.50 & 8 & 121 & 121 & 121.00 & 20 \\
\hline 19 & 144 & 122 & 90 & 139 & 123.75 & 18 & 118 & 129 & 123.50 & 24 \\
\hline 20 & 130 & 110 & 96 & 106 & 110.50 & 2 & 93 & 119 & 106.00 & 7 \\
\hline 21 & 135 & 125 & 103 & 119 & 120.50 & 13 & 95 & 117 & 106.00 & 8 \\
\hline 22 & 136 & 120 & 101 & 119 & 119.00 & 9 & 83 & 113 & 98.00 & 1 \\
\hline 23 & 136 & 122 & 105 & 119 & 120.50 & 12 & 87 & 112 & 99.50 & 2 \\
\hline 24 & 133 & 135 & 106 & 122 & 124.00 & 19 & 114 & 133 & 123.50 & 23 \\
\hline \multicolumn{11}{|c|}{ MEANS : } \\
\hline \multicolumn{7}{|c|}{135.88} & \multicolumn{4}{|c|}{103.42} \\
\hline \multicolumn{7}{|c|}{118.75} & \multicolumn{4}{|c|}{120.46} \\
\hline \multicolumn{7}{|c|}{101.21} & \multicolumn{4}{|c|}{117.77} \\
\hline \multicolumn{11}{|c|}{124.21} \\
\hline & & & & & 120.04 & & & & & \\
\hline
\end{tabular}


the Home Provider is the individual that spends more time with the client than any other person in the client's life. Whether or not the client accurately expressed his willingness to communicate with that Individual, the client would probably know that his training had taught him that the Home Provider's role was important. Therefore, if the client would actually not want to talk with this person he might be tempted to say he would, just to please, than he might be with the other target people.

It 18 also interesting to note that the target person whom the client rates lowest in verbal accessibllity score is that of his "closest frlend." This suggests that this sample population may find it difficult to formulate a friendship with a peer with whom he feels free to share his innermost feelings. One would wonder if the cllent's low verbal accessibility score to the friend target is more important than the high verbal accessibility score to the Home Provider.

One might also note that there is considerable difference between the Counselor's rating and the Home Provider's rating. This can be seen vividly in Table III which shows the percent of each rating who express a positive response of elther "Definitely Yes," or "Probably Yes."

\section{Data Analys 1s}

As I was not able to ut1lize the computer for analysis I was definitely limited by the degree of analysis that could be done in a reasonable period of time. I was able to make use of 
TABLE III

PERCENT OF POSITIVE RESPONSES

\begin{tabular}{|c|c|c|c|c|c|c|}
\hline Item & $\begin{array}{l}\text { Counselor } \\
\text { Rating }\end{array}$ & $\begin{array}{l}\text { Home } \\
\text { Provider } \\
\text { Rating }\end{array}$ & $\begin{array}{l}\text { Client to } \\
\text { Home } \\
\text { Provider }\end{array}$ & $\begin{array}{l}\text { Client to } \\
\text { Relat1ve }\end{array}$ & $\begin{array}{l}\text { Client to } \\
\text { Frlend }\end{array}$ & $\begin{array}{l}\text { Client to } \\
\text { Counselor }\end{array}$ \\
\hline 1 & $62 \frac{1}{2}$ & $82^{\frac{1}{2}}$ & $77 \frac{1}{2}$ & $62 \frac{1}{2}$ & $52 \frac{1}{2}$ & 50 \\
\hline 2 & 30 & $67 \frac{1}{2}$ & $77 \frac{1}{2}$ & 85 & $52 \frac{1}{2}$ & $77 \frac{1}{2}$ \\
\hline 3 & 35 & 80 & 80 & $77 \frac{1}{2}$ & $62 \frac{3}{2}$ & $77 \frac{1}{2}$ \\
\hline 4 & 40 & $82 \frac{1}{2}$ & $87 \frac{1}{2}$ & $72 \frac{3}{2}$ & 70 & $80^{\circ}$ \\
\hline 5 & 55 & 55 & $87 \frac{1}{2}$ & 85 & $67 \frac{1}{2}$ & $92 \frac{1}{2}$ \\
\hline 6 & $57 \frac{1}{2}$ & 60 & 70 & $57 \frac{1}{2}$ & 50 & 55 \\
\hline 7 & 65 & 70 & 70 & 70 & $57 \frac{1}{2}$ & $72 \frac{1}{2}$ \\
\hline 8 & 70 & 80 & $92 \frac{1}{2}$ & $82^{\frac{1}{2}}$ & $62 \frac{1}{2}$ & $75^{\circ}$ \\
\hline 9 & 65 & $67 \frac{1}{2}$ & 80 & $70^{\circ}$ & $473 \frac{1}{2}$ & 75 \\
\hline 10 & $77 \frac{1}{2}$ & $82 \frac{31}{2}$ & $87 \frac{1}{2}$ & $57 \frac{1}{2}$ & $52 \frac{1}{2}$ & $77 \frac{1}{2}$ \\
\hline 11 & 35 & $52 \frac{1}{2}$ & 90 & 60 & $52 \frac{1}{2}$ & $72 \frac{3}{2}$ \\
\hline 12 & $47 \frac{1}{2}$ & $67 \frac{1}{2}$ & 65 & 55 & $47 \frac{1}{2}$ & $67 \frac{1}{2}$ \\
\hline 13 & $67 \frac{1}{2}$ & $72 \frac{3}{2}$ & $87 \frac{1}{2}$ & 75 & 45 & $77 \frac{1}{2}$ \\
\hline 14 & 80 & 80 & 80 & 70 & 50 & 85 \\
\hline 15 & 40 & 70 & $87 \frac{1}{2}$ & 80 & 55 & 80 \\
\hline 16 & 60 & $80=$ & $87 \frac{1}{2}$ & 80 & $47 \frac{1}{2}$ & 80 \\
\hline 17 & 70 & $67 \frac{1}{2}$ & $72 \frac{1}{2}$ & 60 & $52 \frac{1}{2}$ & $82^{\frac{1}{2}}$ \\
\hline 18 & $77 \frac{1}{2}$ & $77 \frac{1}{2}$ & 80 & 60 & 60 & $87 \frac{1}{2}$ \\
\hline 19 & $77 \frac{1}{2}$ & $82 \frac{3}{2}$ & 90 & $67 \frac{1}{2}$ & $47 \frac{1}{2}$ & 90 \\
\hline 20 & 35 & 65 & $77 \frac{1}{2}$ & $62 \frac{1}{2}$ & $47 \frac{1}{2}$ & 60 \\
\hline 21 & 40 & $67 \frac{1}{2}$ & $77 \frac{1}{2}$ & $77 \frac{1}{2}$ & 55 & $72 \frac{1}{2}$ \\
\hline 22 & 20 & 50 & 80 & $72 \frac{3}{2}$ & $52 \frac{1}{2}$ & $67 \frac{1}{2}$ \\
\hline 23 & $27 \frac{1}{2}$ & $57 \frac{1}{2}$ & 80 & $72 \frac{1}{2}$ & $62 \frac{1}{2}$ & 70 \\
\hline 24 & $82 \frac{1}{2}$ & 85 & $77^{\frac{1}{2}}$ & $82 \frac{1}{2}$ & $62 \frac{1}{2}$ & $77 \frac{1}{2}$ \\
\hline MEAN & $55 \%$ & $71 \%$ & $81 \%$ & $71 \%$ & $55 \%$ & $75 \%$ \\
\hline
\end{tabular}


an electronic calculator at Falrview Hospital to compute means, three correlations and several chi-squares.

The first correlation was between the mean self-avowed verbal accessibility scores of the twenty-four items and that of the mean of the other people's rating scores. These are the fugures from Table II. The calculated correlation was $r=.99762$. This seems to be an extremely high correlation. When one finds such a high correlation, one must necessarily check and re-check computations and method carefully. This has been done and no error can be found. The formula used was the standard formula for computing a linear coefficient of correlation when deviations are taken from the means of the two distributions (Garrett, 1958). It is as follows:

$$
\gamma=\frac{\sum x y}{\sqrt{\left(\sum x^{2}\right)\left(\sum y^{2}\right)}}
$$

The computation procedures which I followed are according to the manual for the Friden 130 Calculator which was used.

The high correlation between the self-avowed verbal accessibility scores and those of the combination of the Counselor and the Home Provider indicates staff members who might be utilizing this scale could expect simflar response patterns from the client as would be found from asking the Counselor and Home Provider combined.

The second correlation was between the self-avowed scores of verbal accessibility to their Friend for the forty clients and 
their individual employment success factor. This factor is the percent of time the client was working from the end of the 0. J. T. contract unt11 December 31,1971 . As seen in Table I In Chapter II, the sample was employed a mean of 36.30 weeks after the 0.J.T. contract expired. This took place in a mean time of 85.00 weeks. The computation for the correlation between the verbal accessibility to the Frlend and the employment success factor resulted in $r=.6023$ which denotes substantial relationship at the .05 leve1 (Garrett, 1958). As there was a positive correlation between these two factors when the Friend's verbal accessibility score was the lowest of all the target people, there was no attempt to make statistical correlations between the employment success factor and the accessibility to the other target people. It is assumed that they would all have even higher correlations. As this is only a preliminary study one does not need complete analysis but rather a significant direction Is felt to be adequate.

As a cross check with this correlation, I computed a correlation between the employment success factor and the means of the combination of the Counselor and Home Provider's ratings. This correlation is $r=.65566$ which also denotes a substantial relationship. This is appropriately similar with that of the previous correlation between the employment success factor and verbal accessibility to the Friend.

I attempted several chi-square data analysis problems but was unable to gain any significant results. I did 
chi-square tests of independence in contingency tables using the variables of "yes" and "no" of the verbal accessibility to the Friend target person and the varlable of below and above $50 \%$ on the employment success factor. The results for the total twentyfour 1tems are shown in Table IV.

TABLE IV

CHI-SQUARE OF V.A. TO FRIEND WITH THE EMPLOYMENT SUCCESS FACTOR

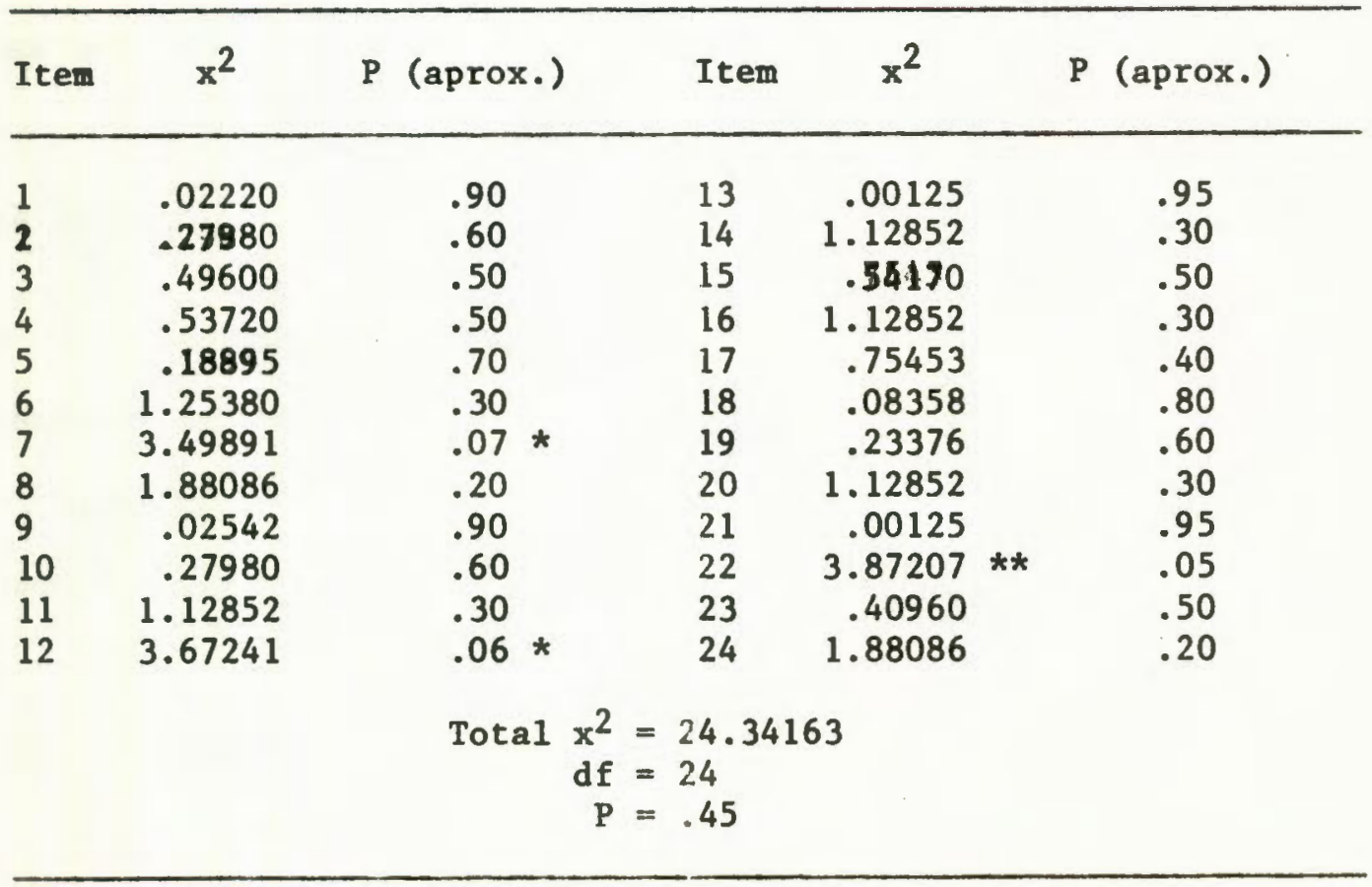

With the exception of 1tems 22,12 , and 7 the chi-square results do not have an adequate probability of exceeding the difference of chance. When the ch1-squares are totaled a df of 24 shows a $P$ of approximately .45 and would have required a $x^{2} .6 f$ 35.172 to be significant at the .05 level. The three questions that showed a significant correlation in excess of normal chance 
probability were 1tems that asked the client to make value fudgments. The large number in the chi-square 1s located in the response of those who stated they would talk with the Friend target person and were at the same time also below $50 \%$ on the employment success factor. My conclusion for these items is that the successful client does not talk with his friemd about areas of value judgment. Perhaps those with exceptional success In this sample decided they wanted to be associated with the "normal" population and shunned their former friends but had not made new friends.

\section{Val1dity}

In this exploratory study of verbal accessibility of the retarded adult, there was no attempt to determine the external validity of the responses by the cllents, the counselors, or the home providers. Statistical analysis would have been inconclusive. 


\section{CHAPTER IV}

\section{EVALUATION AND TMPLICATIONS}

The study reported here was an attempt to clarify one concept, verbal accessibility, within the study and work with the retarded adult population being placed outside the institution into community work and living situations. Professional social work intervention with this population is directed toward changing behavior by influencing changes in problemrelated attitudes. Verbal communication 18 the primary means by which this is accomplished. Th1s involves more than just facts or feelings but the attitudes which characterize the Individual.

I administered my scale to forty individuals who had been trained at Fairview Hospital and Training Center in the 1969-70 Manpower Development Training Act program. Most of the sample was then placed on an 0 . J. T. contract with an employer In the community.

\section{Theoretical Implications}

There was a high percent of positive responses directed toward the Home Provider as a target person. This can be Interpreted as indicating that the 1tems may have been nondiscriminating in nature. However, it also may appropriately indicate that the Home Provider is the most important person 
In the retarded adult's life.

The positive nature of the repponses to the counselor tends to indicate that the client feels that this individual is supposed to be important in his 11fe. As the majority of the testing sessions were not located in an area closely associated with the institutional authority there should not have been excessive pressure on the client to present himself in an excessively good light to please the counselor. The client was also told that the results would not be shared with the counselor unless at the client's request. In contrast with this aspect is the real1ty that I also represented the same institution in their eyes although I was not their counselor.

With the exception of the computations of the means in Table I, there was no attempt to evaluate possible differences between men and women. Had there been better use of a computer for analysis there might have been interesting results through breaking the data down according to sex as there does seem to be considerable difference between the sexes in the employment performance of their placement.

\section{Clinical Implications}

The soclal work profession has traditionally depended upon the Interview to understand and open up the patterns of interaction between people. Besides looking for items of historical signiflcance the social worker also seeks to understand the attitudes which are evident in the client's 
personality. If such a scale as I developed can accurately measure the verbal accessibility of the individual retarded adult it should be of practical value to the social worker both In evaluating the readiness for placement and in the evaluating of cllent's readiness for even more independent living situations later.

For the majority of the clients tested they had never apparently been asked questions of this nature. It is possible that this experience will have a therapeutic effect and encourage them to seek out people with whom they will comnunicate.

The counselors who were involved in the study have expressed varied responses. Most have expressed a wait-and-see approach with interest but 11ttle commitment. This is appropriate as this or no other single method of evaluating a client's readiness for placement will be the complete answer.

\section{Implications for Further Research}

The mechanical procedures for the administration of the scale were smooth in operation and are usable for both further research as well as clinical evaluations of clients. There should be more refinement of test questions along with more data evaluation as to the relationship of the individual question to varlous factors.

In this study I was unable to compare the factor of 
verbal accessibllity with a job skill factor such as might be taken from psychological tests, aptitude tests, and on-job supervisor's evaluations. This would provide an interesting follow-up study. 


\section{BIBLIOGRAPHY}

Appelberg, Esther. Verbal accessibility of adolescents. Doctoral dissertation. Cleveland, Western Reserve University, 1961.

E11is, Norman R. (ed.). International review of research in mental retardation. New York, Academic Press, 1966-1970. 4 vols.

Garrett, Henry E. Statistics in psychology and education. New York, David McKay Company, Inc., 1964.

Jourard, Sidney and Paul Lasakow. Some factors in selfdisclosure. Jouraal of Abnormal and Soctal Psychology $56: 91-98,1958$.

Kresse, Barbara F. et al. Verbal Accessibility in Marriage. Master's thesis. Portland, Oregon. Portland State University School of Social Work, 1967.

Mental retardation abstracts. Washington, D.C., U.S. Department of Health, Education and Welfare, 1964-1972. 9 vols.

Metz, Linda Loulse et al. Verbal accessibility and authoritarian family idealogy. Master's thesis. Portland, Oregon. Portland State University School of Social Work, 1969.

Operating instructions for friden 130 electronic calculator. Rochester, Friden Educational Center, 1964.

Polansky, Norman A. The concept of verbal accessibility. Smith College Studies in Social Work 36:1-48, 1965.

Polansky, Norman A., Erwin S. Welss and Arthur Blum. Children's verbal accessibility as a function of content and personality. American Journal of Orthopsychiatry 31:153-169, Jan., 1961.

President's Panel on Mental Retardation. Bibliography of world 1iterature on mental retardation:, January, 1940 - March, 1963. Washington, D.C., U.S. Department of Health, Education and Welfare, 1964.

Ruesch, Jurgen and Gregory Bateson. Communication: the social matrix of psychiatry. New York, Norton, 1951. 
Stevens, Harvey A. and R1ck Heber (eds.). Mental retardation: a review of research. ChIcago, University of ChIcago Press, 1964.

Walker, Patricla et al. Verbal accessibility between marleal partners as studied in a court of domestic relations. Master's Thesis. Portland, Oregon. Portland State University School of Soctal Work, 1968.

Watts, Mary E. Selected annotated blbllography on mental retardation for social workers. Washington, D.C., U.S. Department of Health, Education and Welfare, 1965. 
APPENDIX 
INSTRUCTIONS TO CLIENTS

I am especially interested in understanding who you talk with about feelings or concerns that are important to you. I am going to ask you about a number of things that happen in everyday life and about feelings people have. Then I will ask you who you would talk with about these things or feelings. I do not want to know if these things have happened to you, but only who you would talk with about them.

I am asking these questions of a number of "fellows and gals" that also received training in the Fairview MDTA Program the same year you did to try to help prepare other trainees to be successful in the community. No one other than me will know how you answered these questions. I w11l not tell your home provider, your friend, your relative or your counselor.

On the table before you, you can see four stacks of different colored cards with the same question typed on each card. Each stack is for a different person with whom you may talk. The first stack--the orange cardd--are marked "номЕ PROVIDER." The white Eards are for a RELATIVE with whom you would be most likely to talk. Which of your relatives would you talk with most about important feelings? (I write first name or title of relative on a white card and place it behind the stack of white cards.) The green cards are for the FRIEND outside your family with whom you would be most likely to talk. Who is that? (I write name on a green card and put it behind 
the stack of green cards.) And the last stack--the yellow cardsare marked COUNSELOR. Who is your counselor? (I put that name on yellow card).

Now, let's look at the sample question which is on the card you see here. Suppose you would like to go to town more offen, would you talk with--(insert the name of the HOME PROVIDER)? Here are four slots where you can put cards. They are marked Definitely Yes, Probably Yes, Probably No, and Definitely No. Now place the top orange card with the SAMPLE QUESTION I have asked you in one of these slots to show how you would discuss this with your home provider. You must assume that you have the chance to talk with this person.

Again, suppose you feel that you would like to go to town more often, would you talk with (relative's name) about it? Place the top white card in one of the slots to show how you would talk with (relative's name) about this.

Again, suppose you would like to go to town more often, would you talk (friend's name) about 1t? Place the top green card in one of the slots to show how you would talk with (friend's name) about this.

Again, suppose you feel you would like to go to town more often, would you talk with your counselor (name) about it? Place the top yellow card in one of these slots to show how you would talk with (counselor's name) about this. 
That was a sample question. Now question number one is on the top card of each stack. Wed11 go through each question just as we have done and you w1ll put each card in one of the slots which answers the question best. If you want me to repeat any of the questions even several times fust ask. 


\section{ATTITUDE STATEMENT MASTER}

The following statements were asked the clients in regard to four TARGET PEOPLE: Home Provider, Relative, Friend, Counselor. The clients could respond in four different ways: Definitely Yes, Probably Yes, Probably No, and Definitely No.

1. Suppose you don't have as much spending money as most fellows and gals, would you talk with .. .

2. Suppose you do not go around with the "right kind" of fellows and gals, would you talk with ... .

3. Suppose your 1deas are not $11 \mathrm{ked}$ by your frlends, would you talk with...

4. Suppose the other fellows or gals think you are different, would you talk with...

5. Suppose you are in a place where you are not sure of yourself, would you talk with...

6. Suppose your home provider is a poor housekeeper, would you talk with...

7. Suppose your home providers do not treat your frlends well, would you talk with...

8. Suppose your home providers do not understand you, would you talk with...

9. Suppose you feel your home providers do things they tell you not to do, would you talk with...

10. Suppose you think the rules your home providers make for you are not good, would you talk with ...

11. Suppose you do things with other fellows and gals when you are out that your home providers do not like, would you talk with...

12. Suppose you would like to tell your boss off, would you talk with... 
13. Suppose your home provider's ideas of how you should act does not let you do the things you want to do, would you talk with...

14. Suppose the job your counselor found for you is not what you want, would you talk with..

15. Suppose your home providers do not tell you if they like or don't like the way you behave away from the house, would you talk with...

16. Suppose your home providers do not trust you on your own away from home, would you talk with ...

17. Suppose you are not getting pald enough for your work, would you talk with...

18. Suppose your boss is not fair with you and other workers, would you talk with...

19. Suppose you would like to get more education or training, would you talk with ...

20. Suppose you were turned down when you asked your girl to the big dance or party, would you talk with... (for males)

Suppose no fellow asked you to go with him to the blg dance or party, would you talk with ... (female)

21. Suppose you are not sure about knowing how to dress well, would you talk with...

22. Suppose you do not know how far to go (sexual advances) on a date, would you talk with . . .

23. Suppose you are not satisfled with your build (figure) would you talk with . .

24. Suppose you want to get marriad, would you talk with ... 
Research \#

Date

INTERVIEW INFORMATION SHEET

Name

FHTC \#

Target People Used:

Home Provider (Orange)

Important Relative (White)

Closest Friend (Green)

Counselor (Yellow)

Agency: (FHTC , MDTA , DVR

Welfare

Present Occupation

Income

How long with Present Employer?

Other Comments as on dress, affect, etc. 
Research \#

SCORE SHEET

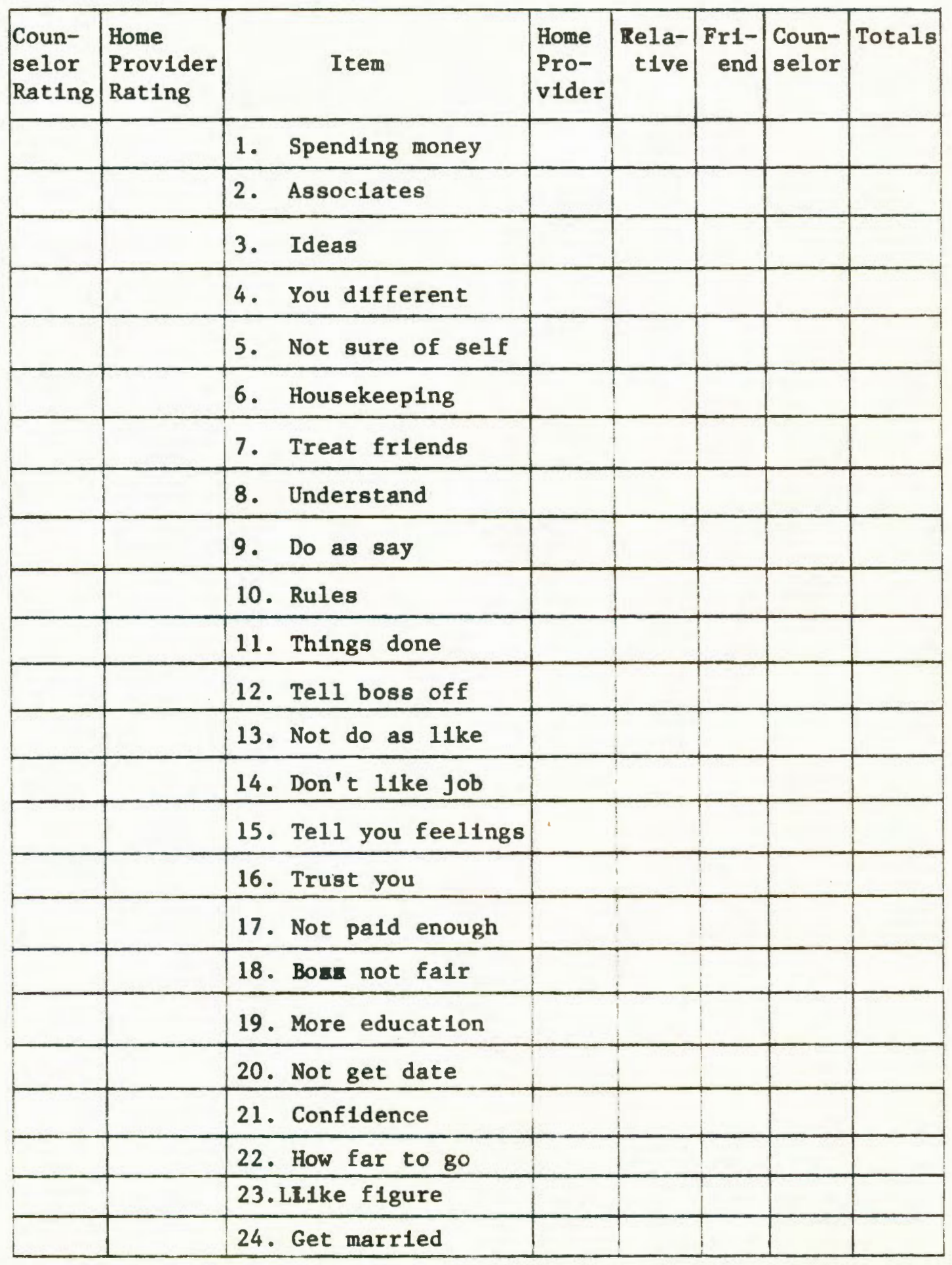


Client Name

Research 非

Case 非

COUNSELOR AND HOME PROVIDER RATING SHEET

The following statements w111 be asked the cllent in regard to four target people. You are asked to make a judgment as to how much the cllent would be wllling to talk about each statement to you. Please respond to each question by putting a check mark in the most appropriate box. Please return this form promptly to Kelth Baker, 2250 Strong Rd. S.E., Salem, Oregon 97310. Thank you for your help.

1. Suppose you don't have as much spending money as most fellows and gals, would you talk with

2. Suppose you do not go around with the "right kind" of fellows and gals, would you talk with ........

3. Suppose your 1deas are not liked by your frlends, would you talk with........

4. Suppose the other fellows and gals think you are different, would you talk with . . .

5. Suppose you are in a place where you are not sure of yourself, would you talk with . . . . . . . .

6. Suppose your home provider Is a poor housekeeper, would you talk with .......

7. Suppose your home providers do not treat your friends well, would you talk with.

\begin{tabular}{|c|c|c|c|}
\hline $\begin{array}{c}\text { Def1- } \\
\text { n1te } \\
\text { YES }\end{array}$ & $\begin{array}{c}\text { Proby- } \\
\text { ably } \\
\text { YES }\end{array}$ & $\begin{array}{c}\text { Prob- } \\
\text { ab1y } \\
\text { No }\end{array}$ & $\begin{array}{c}\text { Def1- } \\
\text { n1te } \\
\text { No }\end{array}$ \\
\hline & & & \\
\hline & & & \\
\hline & & & \\
\hline & & & \\
\hline & & & \\
\hline & & & \\
\hline & & & \\
\hline & & & \\
\hline
\end{tabular}


8. Suppose your home providers do not understand you, would you talk with .......

9. Suppose you feel your home providers do things they tell you not to do, would you talk with . . . . . .

10. Suppose you think the rules your home providers make for you are not good, would you talk with . . . . . . .

11. Suppose you do things with other fellows and gals when you are out that your home providers do not like, would you talk with . . . . . .

12. Suppose you would like to tell your boss off, would you talk with . . . . .

13. Suppose your home provider's ideas of how you should act does not let you do the things you want to do, would you talk with . . . . . .

14. Suppose the fob your counselor found for you is not what you want, would you talk with ........

15. Suppose your home providers do not tell you if they like or don't like the way you behave away from the house would you talk with ....

16. Suppose your home providers do not trust you on your own away from home, would you talk with . . . . . .

17. Suppose you are not getting pald enough for your work would you talk with... .

18. Suppose your boss is not falr with you and other workers, would you talk with

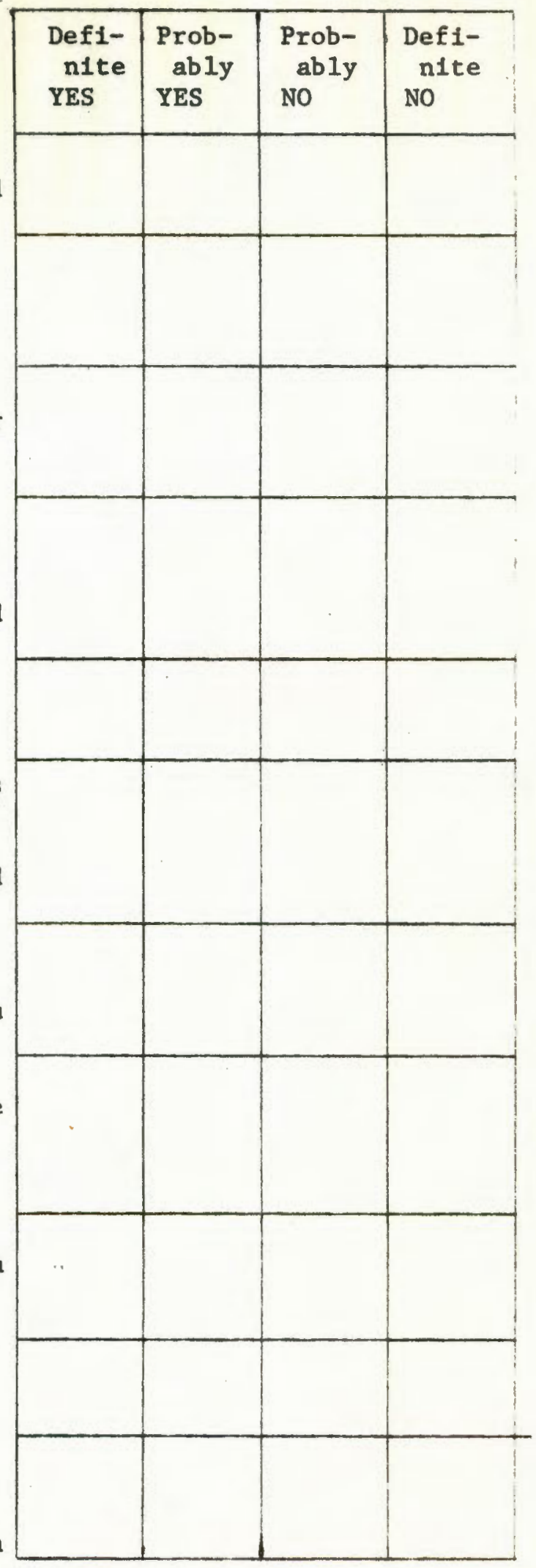


19. Suppose you would l1ke to get more education or training, would you talk wtth . . . . . . . .

20. Suppose you were turned down when you asked your g1rl to the $\mathrm{b}_{8} \mathrm{~d}$ dance or party, would you talk with... .

21. Suppose you are not sure about knowing how to dress we1l, would you talk with.

22. Suppose you do not know how far to go (sexual advances) on a date, would you talk with

23. Suppose you are not sat1sfled with your bulld, would you talk with....

24. Suppose you want to get marrled would you talk with .........

\begin{tabular}{|c|c|c|c|}
\hline $\begin{array}{c}\text { Def1- } \\
\text { n1te } \\
\text { YES }\end{array}$ & $\begin{array}{c}\text { Beob- } \\
\text { ab 1y } \\
\text { YES }\end{array}$ & $\begin{array}{c}\text { Prob- } \\
\text { ab1y } \\
\text { No }\end{array}$ & $\begin{array}{c}\text { Def1- } \\
\text { n1te } \\
\text { No }\end{array}$ \\
\hline & & & \\
\hline & & & \\
\hline & & & \\
\hline & & & \\
\hline
\end{tabular}

